Transportation Research Forum

Economic Effects of Lifting the Spring Load Restriction Policy in Minnesota

Author(s): Brian Smalkoski, Ning Li, and Dr. David Levinson

Source: Journal of the Transportation Research Forum, Vol. 45, No. 2 (Summer 2006), pp. 45-55

Published by: Transportation Research Forum

Stable URL: http://www.trforum.org/journal

The Transportation Research Forum, founded in 1958, is an independent, nonprofit organization of transportation professionals who conduct, use, and benefit from research. Its purpose is to provide an impartial meeting ground for carriers, shippers, government officials, consultants, university researchers, suppliers, and others seeking exchange of information and ideas related to both passenger and freight transportation. More information on the Transportation Research Forum can be found on the Web at www.trforum.org. 


\title{
Economic Effects of Lifting the Spring Load Restriction Policy in Minnesota
}

\author{
by Brian Smalkoski, Ning Li, and Dr. David Levinson
}

Spring load restrictions (SLR) regulate the weight per axle carried by heavy trucks during the spring thaw period. This policy aims to reduce pavement damage caused by heavy vehicles and extend the useful life of roads, but it also imposes costs on the trucking industry. A cost/benefit study, based on the results of surveys of industry costs, a pavement performance model, and a freight demand model, concludes that the benefits of lifting the existing SLR policy outweigh the additional costs. The cost of additional damage should be recovered from those who benefit from the change in policy.

\section{INTRODUCTION}

Spring load restrictions (SLR) limit the axle loads of heavy trucks during the spring thaw period. The SLR policy has been implemented in many cold climate countries, including the United States, Canada, France, Norway, Finland, and Sweden. The policy aims to reduce pavement damage and extend the useful life of roads, which enables road authorities to save on maintenance costs. However, the SLR policy also imposes costs on the trucking industry due to detouring or increased number of truckloads. A question naturally arises: Does the benefit really exceed the cost? The trucking industry complains that the SLR policy imposes costs and inconvenience, while the road agency strongly advocates this policy because it reduces required pavement investment and maintenance costs. Although the SLR policy has been implemented for many years, it has not been studied extensively.

Road agencies and the trucking industry acting on behalf of their own interests are susceptible to favor a conclusion that brings them an economic advantage. A World Bank report indicates that the estimated cost savings associated with SLR during an extreme (20-year) winter in Europe are substantial, ranging from $40 \%$ up to $92 \%$, with an average of $79 \%$ for the countries analyzed (Isatolo 1993). The Norwegian Public Roads Administration showed that the cost of SLR exceeded its benefit, which led to the lifting of its SLR policy in 1995 (Refsdal 1998). After eight years of experiments, the Norwegian road agency concluded that there was no indication of reduced road surfacing serviceability due to the lifting of SLR and the actual annual budgets for resurfacing during the same period have been considerably reduced (Refsdal, Senstad, and Soerlie 2004).

Unclear conclusions can be drawn from the above analyses, which reflect the complexity of quantifying the actual benefits and costs of SLR. However, the inconsistency does not necessarily indicate one or another study is wrong. It is important to understand that the effects of SLR could vary in different regions because of differences in climates, soil conditions, structural designs, truck traffic patterns, and a different hierarchy of road networks.

The Minnesota Local Road Research Board (LRRB) and the Minnesota Department of Transportation (Mn/DOT) sponsored a cost/benefit study of spring load restrictions in Minnesota, which was completed in 2005 (Levinson, Marasteanu, Voller, Margineau, Smalkoski, Hashami, Li, Corbett, Funk, Zou, Peterson, Nagel, and Peterson 2005). The study is based on the results of mailed revealed preference surveys of costs and stated preference surveys of value of time, a pavement performance model, and a freight demand model. This paper reports the results of the study. First the framework of the benefit/cost analysis is presented. This includes a discussion of the surveys and models used in the analysis. This is followed by the results of the economic analysis. The conclusions summarize the report's policy conclusions. 
Spring Load Restriction Policy

\section{FRAMEWORK OF BENEFIT/COST ANALYSIS OF MINNESOTA SLR}

Estimating the impact of the SLR policy on the economy requires a careful analysis within a benefit/ cost evaluation framework. The benefits of lifting the SLR policy include reduced economic costs imposed on carriers and shippers (and ultimately consumers, workers, and businesses) associated with less additional distance traveled to avoid restricted roads, fewer truckloads needed to abide by the restriction, and fewer deferred/delayed shipments. The costs of lifting the SLR policy for state and local governments (and ultimately taxpayers and road users in Minnesota) include reduced pavement life.

Three Minnesota counties, Lyon, Clay, and Olmsted, were modeled in extensive detail to estimate the economic effect of the SLR policy for the state. These counties represent typical regions in Minnesota. Lyon County is used herein as an example to explain the methodology.

Estimating the benefits requires an assessment of freight demand patterns and truck operating costs. Estimating the costs of changing the policy also requires measurement of pavement performance and pavement construction cost. A flowchart of the framework for analyzing the benefits and costs of SLR is shown in Figure 1 and is detailed below (Levinson, Li, Zou, Smalkoski, and Hashami 2004).

Figure 1: Flow Chart of the SLR Benefit/Cost Analysis

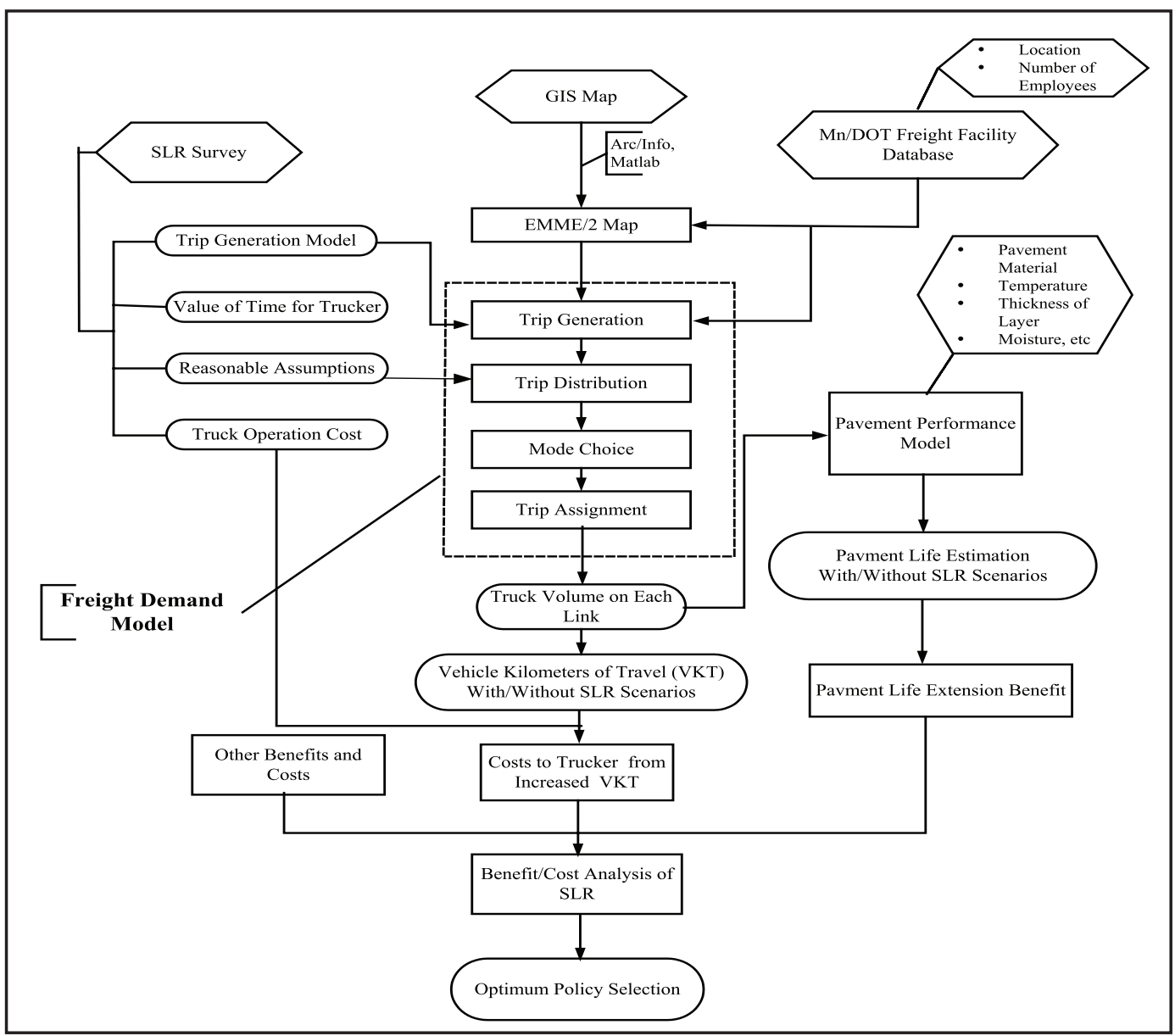




\section{Surveys}

To prepare for the benefit/cost analysis, a mailed survey was conducted in 2003. The surveys were mailed before, during, and after the SLR period. More than 2,500 surveys were mailed to freight facilities, trucking association members, and significant commercial truckers identified through a separate city/county engineer survey conducted by Mn/DOT. The mailed survey resulted in 441 responses, from which a sample of 50 interviews were conducted in and around the three counties to be modeled. The follow-up interviews also included an adaptive stated preference survey to determine the value of time for commercial vehicle operators. The surveys aimed to provide SLR background information, such as truck operating cost, value of time, and trips generated for each freight facility type, which could be used in the benefit/cost analysis.

Several models were fit to determine truck operating cost and value of time based on the survey results. Hashami (2004) stated that the average operating cost per kilometer from the survey responses was $\$ 0.69$ per kilometer. Smalkoski (2005) estimated the value of time for commercial vehicle operators as $\$ 49.42$ per hour.

\section{Trip Generation Model}

A truck trip (truckloads) generation model was determined from the mailed SLR survey to calculate truck trips generated in the modeling area. Trip generation rates varied by freight facility type (grain elevator, retail outlet, farm, etc.), thus separate models were calculated for each type. The truck trip generation model adopted a Cobb-Douglas model form, and uses the number of truckloads generated per day as dependent variable and the number of direct employees in each freight facility as the independent variable.

(1) $T L=e^{\beta 1} \times D E^{\beta 2}$

where:

$T L=$ Number of truckloads generated per day

$e=$ Euler's constant $(2.718 \ldots)$

$D E=$ Number of direct employees

$\beta_{1}, \beta_{2}=$ Model coefficients

Freight facilities in the modeling area were located using the Mn/DOT freight facility database.

\section{Freight Demand Model}

A freight demand model was developed to simulate truck flow under two scenarios: with and without SLR. It was also used as an input for the pavement performance model mentioned hereafter.

The first step was to obtain the data needed for modeling. Again, detailing Lyon County as an example, a county GIS map with traffic volumes on most of the roads was obtained from the county engineer together with a detailed road restriction map.

All roads in Lyon County, including trunk highways, county, city, and township roads are classified into four types: 5-, 7-, 9- and 10-ton roads. There are four corresponding modes in the freight demand model: 'c', 'l', 'm', 'h', which are explained in Table 1. It is assumed that there are three typical types of trucks (two-axle, three-axle and five-axle) in the model, and their configuration and percentage are listed in Table 2. In Lyon County there are 225 traffic analysis zones (TAZs) evenly located within the county. Since Lyon County is largely an agricultural county, we can think of each of these TAZs as a virtual farm.

Four-step modeling techniques were implemented to estimate the truck flow on each link of the road network under different traffic scenarios. EMME/2, a transportation planning software, was used to conduct route assignment. 
Table 1: Modes in the Freight Demand Model

\begin{tabular}{llc}
\hline Mode & Representation & Allowed road types to operate on \\
\hline C & $\begin{array}{l}\text { truck with small loads } \\
\text { (5 tons per axle or less) }\end{array}$ & 5,7, 9,10-ton roads \\
l & $\begin{array}{l}\text { truck with light loads } \\
(5-7 \text { tons per axle) }\end{array}$ & 7,9,10-ton roads \\
& $\begin{array}{l}\text { truck with moderate loads } \\
\text { (7-9 tons per axle ) }\end{array}$ & 9,10-ton roads \\
h & heavy truck & 10-ton roads only \\
\hline
\end{tabular}

Trip generation. It is assumed that the truck demand is generated from various kinds of freight facilities within the county. Eight types of freight facilities were located in Lyon County through the Mn/DOT freight facility database classification: Farm, Agriculture Chemical Center, Grain Elevator, Manufacturing Plant, Retail Outlet, Trucking Facility, Wholesale Distribution Center, and Other Freight Facilities. Daily truck trips generated by each freight facility were calculated using the trip generation model developed from the SLR surveys.

Trip Distribution. Trip distribution is based on the origin-destination schematic in Figure 2. It is assumed that each farm will deliver their grain product to the nearest grain elevator and return empty. Each farm receives deliveries from the nearest agricultural chemical facility and the trucks return to the facility empty. For the other types of freight facilities, it is assumed all traffic is bound for locations outside Lyon County. The trips to each external station are distributed in proportion to the real traffic count at these external points. There is also external-to-external traffic, which is assumed to be $20 \%$ of the total traffic stream on each link to an external station.

Vehicle Type Assignment. It is assumed that truckers will choose the most economically beneficial vehicle. In the absence of restrictions, truckers will tend to choose the heaviest trucks available so they can carry more goods. However, weight restrictions may prevent this, especially if a trucker would face a significant amount of detouring. Truckers faced with weight restrictions must compare the costs (see the following formula) of detouring versus the costs of using trucks with a lower weight or payload capacity, which may result in using more trucks. The total cost for a trip is:

(2) $C=\left(T_{T}+T_{L}\right) * N * c$

where:

$C=$ Total cost

$T_{T}=$ Travel time for each trip (hours)

$T_{L}=$ Time for loading and unloading (assuming 0.5 hour)

$N=$ Number of truckloads

$c=$ Value of time (dollars per hour)

Route Assignment. In the route assignment, it is assumed that truckers will behave according to user equilibrium assignment theory in which they will choose routes with the least travel time (T). Since rural areas are being modeled, congestion effects are ignored, which makes this equivalent to an all-or-nothing shortest path assignment. The volume-delay function in this model is as follows:

(3) $T=60 * L / v$ 
Figure 2: Freight Demand Pattern in Lyon County

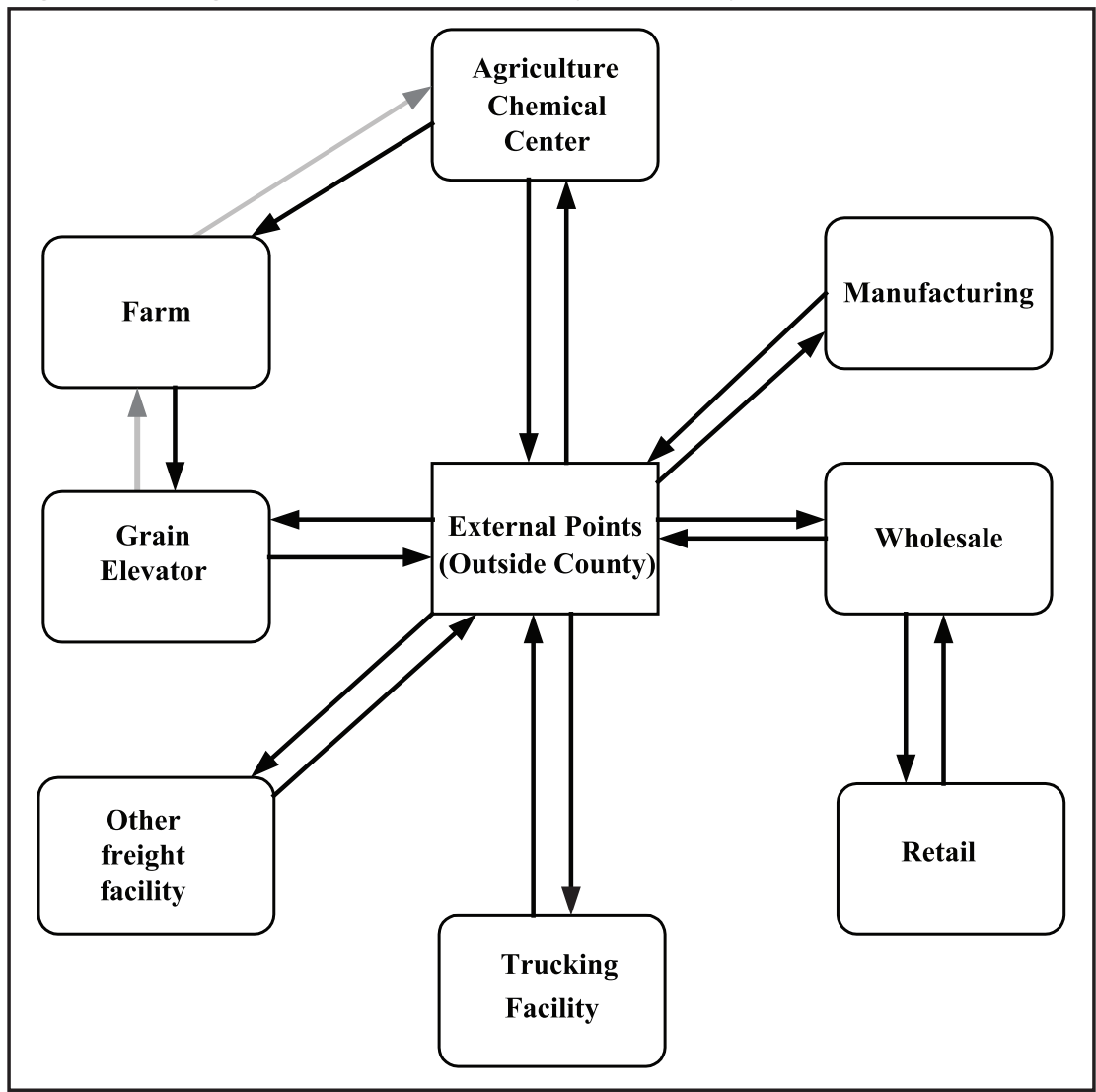

Light color arrows indicate empty load trips.

where:

$T=$ Travel time (minutes)

$L=$ road section length (kilometers)

$V=$ vehicle speed $(\mathrm{km} / \mathrm{h})$, assumed to be 48, 64, 80 and $96 \mathrm{~km} / \mathrm{h}$ (30, 40, 50, and $60 \mathrm{mph})$ for 5-, 7-, 9- and 10-ton roads respectively. Interstate highways are assigned a speed of $104 \mathrm{~km} / \mathrm{hr}(65 \mathrm{mph})$, The constant "60" converts hours to minutes.

Model Calibration. The freight demand model simulates truck volume on each link of the road network. The volume from the model is compared and calibrated using observed truck traffic counts. In Lyon County, data were collected at 52 sites during the period without SLR. Figure 3 compares the model simulations with actual observations. It can be seen from the plot that the two data sets have a strong linear relationship. In order to find how close the model reflects the actual conditions, a linear model with zero intercept was fit to the data (Equation 3). It is important to note that a zero intercept is assumed to avoid negative traffic counts in the model.

(4) $Y=\beta_{1} * x$

where:

$\mathrm{Y}=$ actual traffic counts

$\mathrm{x}=$ modeled traffic volume

$\beta_{1}=$ model coefficient (1.26) has an $\mathrm{R}^{2}$ value of 0.83

The linear model indicates a $26 \%$ adjustment factor should be implemented to calibrate the model results (i.e. $\beta_{1}=1.26$ ). 
Figure 3: Plot of Model Versus Observed Truck Average Daily Traffic (ADT) for Lyon County

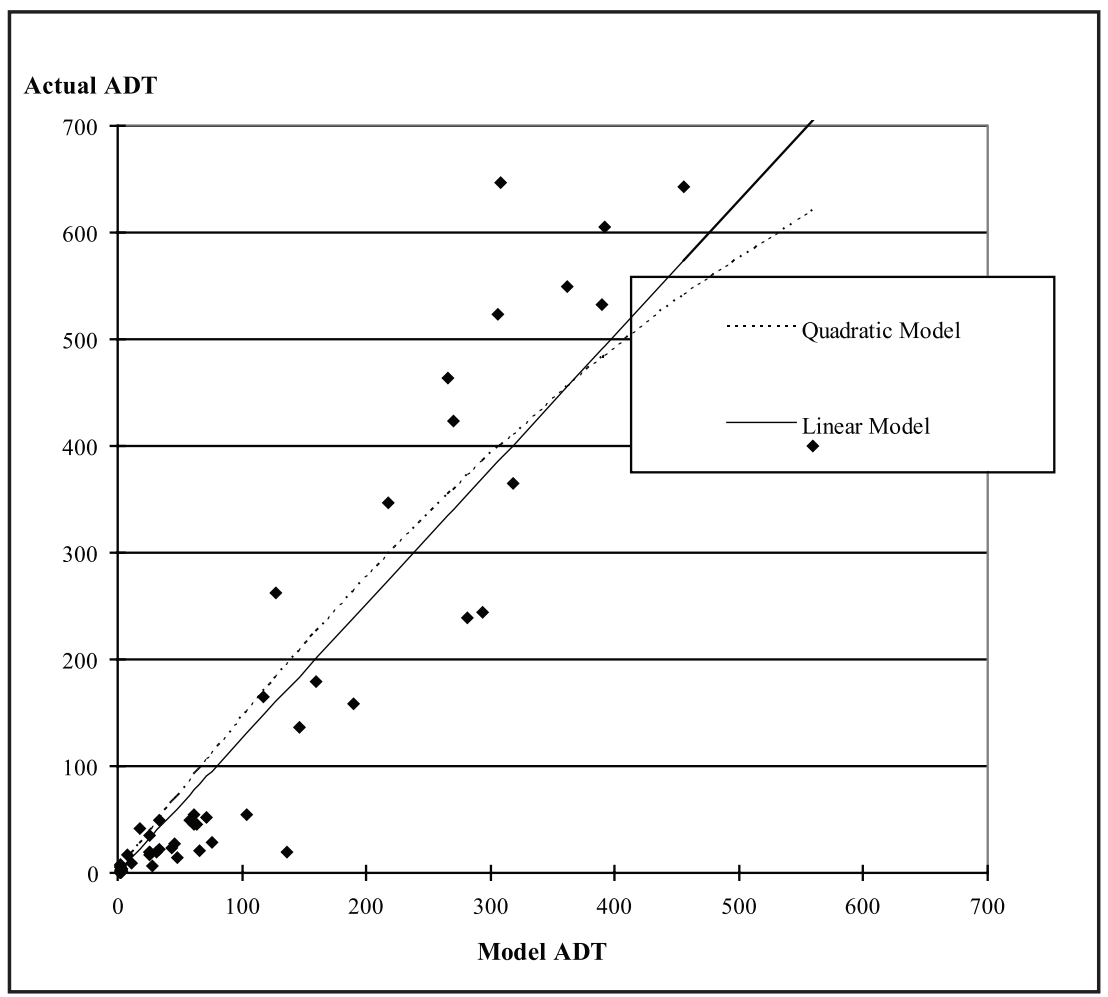

\section{Pavement Performance Model}

The freight demand model provides calibrated truck volumes by type on each section of the road network as an input to the pavement performance model. The pavement performance model used in this analysis is the software MnPAVE, a mechanistic-empirical model provided by Mn/DOT (Levinson, Li, Zou, Smalkoski, and Hashami 2004). The pavement performance model estimates the pavement life in terms of rutting failure. Rutting failure represents the most frequent cause of failure on local roads according to this model.

It is assumed there are three types of trucks in the road network. Their configuration is shown in Table 2. Coefficient damage factors are calculated for all these types of trucks when they run on 5-, 7- and 9-ton roads respectively. The MnPAVE model pavement performance model calculates the damage each truck imposed on the pavement, assuming certain pavement structural configurations for each road type, and estimates the pavement life in terms of rutting failure. In Lyon County, it is assumed that 7-ton roads are built of 3" asphalt on 6" granular base and 9-ton roads are built on 3.5" asphalt on 15" granular base according to the survey. Also, it was assumed that $50 \%$ of roads are built on A6 soil and 50\% on A7 soil (A6 and A7 are silt-clay soil types in the American Association of State Highway and Transportation Officials soil classification system). 
Table 2: Truck Configuration and Percentage on Different Types of Roads

\begin{tabular}{lcccccc}
\hline $\begin{array}{c}\text { Truck } \\
\text { Configuration }\end{array}$ & $\begin{array}{c}\text { Net Vehicle } \\
\text { Weight } \\
\text { (tons) }\end{array}$ & $\begin{array}{c}\text { Gross } \\
\text { Vehicle } \\
\text { Weight } \\
\text { (tons) }\end{array}$ & $\begin{array}{c}\text { Payload } \\
\text { (tons) }\end{array}$ & $\begin{array}{c}\text { Weight } \\
\text { Restriction } \\
\text { (tons) }\end{array}$ & $\begin{array}{c}\text { Actual } \\
\text { Carrying } \\
\text { Capacity } \\
\text { (tons) }\end{array}$ & $\begin{array}{c}\text { Proportion } \\
\text { of Fleet } \\
\text { Using a } \\
\text { Route }\end{array}$ \\
\hline 5-Ton Route & Carrying capacity of a typical 5 ton truck & 4 & \\
2 Axle Truck & 3.4 & 12 & 8.6 & 7.3 & 3.9 & $85.40 \%$ \\
3 Axle Truck & 8 & 21 & 13 & 12.9 & 4.9 & $14.60 \%$ \\
7-Ton Route & Carrying capacity of a typical 7 ton truck & 8.8 & \\
2 Axle Truck & 3.4 & 12 & 8.6 & 10.2 & 6.8 & $54.20 \%$ \\
3 Axle Truck & 8 & 21 & 13 & 18.1 & 10.1 & $29.70 \%$ \\
5 Axle Truck & 14.4 & 39 & 24.6 & 27.8 & 13.4 & $16.10 \%$ \\
9-Ton Route & Carrying capacity of a typical 9 ton truck & 13 & \\
2 Axle Truck & 3.4 & 12 & 8.6 & 13.1 & 8.6 & $47.50 \%$ \\
3 Axle Truck & 8 & 21 & 13 & 23.6 & 13 & $27.10 \%$ \\
5 Axle Truck & 14.4 & 39 & 24.6 & 35.7 & 21.3 & $25.30 \%$ \\
10-Ton Route & Carrying capacity of a typical 10 ton truck & 17.4 & \\
2 Axle Truck & 3.4 & 12 & 8.6 & $>13.1$ & 8.6 & $24.80 \%$ \\
3 Axle Truck & 8 & 21 & 13 & $>23.6$ & 13 & $9.80 \%$ \\
5 Axle Truck & 14.4 & 39 & 24.6 & 35.7 & 24.6 & $65.40 \%$ \\
\hline
\end{tabular}

\section{ECONOMIC ANALYSIS}

The benefit/cost analysis combines the freight demand model, pavement performance model, and cost information derived from the mailed and stated preference surveys. The freight demand model estimates changes in vehicle kilometers traveled (VKT) due to the imposition of the SLR policy. These results are then multiplied by the total operating cost per kilometer to determine the economic benefit of removing the SLR policy. The economic cost is the net present value of increased maintenance costs as a result of poorer pavement performance. The pavement performance model estimates the change in pavement life cycle maintenance as a result of the SLR policy. This result multiplied by maintenance costs determines the cost of removing the policy.

\section{Benefit}

The benefit of removing the SLR policy is assumed to be the reduction of vehicle kilometers of travel and travel time in order to comply with the restrictions. Trucks must run less than full, detour, or change vehicle type in order to comply; all of these options increase kilometers traveled and time. The freight demand model estimates the reduction of VKT and travel time as a result of lifting the policy. Table 3 indicates the benefit based on VKT and total operating cost per kilometer of removing the SLR policy for the three studied counties. 
Spring Load Restriction Policy

Table 3: Reduced Operating Cost to Truckers from Removal of SLR Policy

\begin{tabular}{lc}
\hline County & Reduced Cost to Truckers \\
\hline Lyon & $\$ 6,057,602$ \\
Olmsted & $\$ 30,549,655$ \\
Clay & $\$ 744,030$ \\
\hline Total & $\$ 37,351,287$ \\
\hline
\end{tabular}

Cost

The increase in pavement maintenance costs represents the primary cost to the road-maintaining agency. The average cost estimates for pavement maintenance (reconstruction and overlays) from a recent survey of State District Engineers in Minnesota is included in Table 4.

The average structural and functional overlay costs for each roadway classification (e.g., 9ton) were multiplied by the length and relative percentage of the roadway network for each studied county. The resulting weighted average cost per kilometer for structural overlays in Lyon County is $\$ 78,028$ for 7 -ton roadways and $\$ 83,450$ for 9-ton roadways; the weighted average cost per kilometer for functional overlays is $\$ 42,113$ and $\$ 42,853$ respectively.

The functional overlays are assumed to last a maximum of 17 years. The pavement performance model MnPAVE estimates the years before rutting failure on a link-by-link basis for both scenarios, with and without SLR in place. For most links, the pavement lasts longer with SLR in place than without. The difference in net present value of maintenance costs is the pavement life extension cost of removing the SLR policy. Net present value assumes a 3.5\% interest rate. Table 5 displays the cost calculation for one link.

Table 4: Average Pavement Costs per Centerline Kilometer

\begin{tabular}{lrcc}
\hline Category & Reconstruct & Structural Overlay & Functional Overlay \\
\hline CSAH 9,10-ton & $\$ 235,938$ & $\$ 66,875$ & $\$ 39,063$ \\
CSAH 7-ton & $\$ 190,625$ & $\$ 72,813$ & $\$ 40,625$ \\
CR 9-ton & $\$ 258,333$ & $\$ 64,583$ & $\$ 34,375$ \\
CR 7-ton & $\$ 171,875$ & $\$ 64,063$ & $\$ 35,938$ \\
CR 5-ton Paved & $\$ 112,500$ & $\$ 34,375$ & $\$ 28,125$ \\
CR 5-ton Aggregate & $\$ 87,500$ & $\$ 31,250$ & N/A \\
MSA 9,10-ton & $\$ 932,813$ & $\$ 233,333$ & $\$ 77,083$ \\
MSA 7-ton & $\$ 729,167$ & $\$ 191,667$ & $\$ 77,083$ \\
Residential Streets & $\$ 1,443,750$ & $\$ 450,000$ & $\$ 51,667$ \\
Township Rd, Paved & $\$ 725,000$ & $\$ 240,625$ & $\$ 50,625$ \\
Township Rd, Aggregate & $\$ 68,750$ & $\$ 18,750$ & $\$ 18,750$ \\
\hline Non
\end{tabular}

Notes: CSAH: County State Aid Highway

CR: County Road

MSA: Municipal State Aid

Source: State District Engineers in Minnesota, G. Isakson (2004). 
Table 5: Increased Cost to Road-Maintaining Agency from Removal of SLR Policy

\begin{tabular}{|c|c|c|c|c|c|c|}
\hline Link 1 & $\begin{array}{l}\text { From } \\
\text { Lengt } \\
\text { No SI } \\
\text { Estim }\end{array}$ & $\begin{array}{l}\text { le id: } 41 \\
\text { rm): } 1.58 \\
\text { scenario } \\
\text { d life (yea }\end{array}$ & & $\begin{array}{l}\text { To no } \\
\text { Cost } \\
\text { With } \\
\text { Estim }\end{array}$ & $\begin{array}{l}\text { d: } 9 \\
\text { km: \$42,1 } \\
\text { Scenari } \\
\text { life (yea }\end{array}$ & \\
\hline Overlay: & Year & Cost & NPC & Year & Cost & NPC \\
\hline $1^{\text {st }}$ overlay & 7.1 & $\$ 66,706$ & $\$ 52,248$ & 7.3 & $\$ 66,706$ & $\$ 51,962$ \\
\hline $2^{\text {nd }}$ overlay & 21.3 & $\$ 66,706$ & $\$ 32,053$ & 21.8 & $\$ 66,706$ & $\$ 31,530$ \\
\hline $3^{\text {rd }}$ overlay & 35.5 & $\$ 32,839$ & $\$ 9,680$ & 36.3 & $\$ 28,455$ & $\$ 8,161$ \\
\hline \multicolumn{3}{|c|}{ Sum of Net Present Cost (NPC) } & $\$ 93,981$ & & & $\$ 91,653$ \\
\hline \multicolumn{4}{|c|}{ Savings due to SLR } & & & $\$ 2,328$ \\
\hline
\end{tabular}

\section{Cost/Benefit Ratio}

The benefit/cost ratio of lifting the SLR policy is indicated in Table 6. The typical overlay interval (assumed to be 17 years) affects the results. Alternative interval assumptions are also included in Table 6.

The results from all three studied counties in Minnesota indicate that the benefits of lifting the SLR policy on 9-ton roadways exceed the increased cost of roadway maintenance for the road maintaining agencies. Additional sensitivity analysis using the calculated value of time instead of operating cost per kilometer was conducted and is consistent with these results.

Table 6: Benefit/Cost Ratio of SLR Policy for Three Studied Counties

\begin{tabular}{cccc}
\hline & \multicolumn{3}{c}{ Benefit/Cost Ratio } \\
\cline { 2 - 4 } $\begin{array}{c}\text { Default Pavement Life } \\
\text { Assumption (years) }\end{array}$ & $\begin{array}{c}\text { Lyon County } \\
\text { (operating costs) }\end{array}$ & $\begin{array}{c}\text { Olmsted County } \\
\text { (operating costs) }\end{array}$ & $\begin{array}{c}\text { Clay County } \\
\text { (operating costs) }\end{array}$ \\
\hline 15 & 21.76 & 16.07 & 3.61 \\
17 & 13.81 & 15.75 & 3.19 \\
20 & 12.1 & 15.33 & 2.6 \\
25 & 9.41 & 14.92 & 2.16 \\
30 & 7.93 & 14.48 & 1.89 \\
\hline
\end{tabular}

\section{CONCLUSION}

The spring load restriction policy has been in place since 1937 (Minnesota Statute 169.87) and has been periodically updated. The results of this investigation recommend repealing the policy on all paved roads rated at 9-tons during non-spring load period. The additional costs for maintaining and repairing roads should be recovered from those that benefit from this policy change.

The additional costs may be recovered through several options: an increase in commercial vehicle annual fees proportionate to the additional amount of damage to the roadways, an increase in the diesel fuel tax to target the trucks that cause additional damage, or a weight-distance tax similar to the one that is currently in place in Oregon. 
Spring Load Restriction Policy

There are a number of annual fees that commercial vehicle operators already pay, so an existing collection system is in place. An average of $\$ 42$ per registered truck/tractors and farm trucks would recover the additional costs. In order to upgrade the 7-ton roadways to 9-tons with a structural overlay, an average annual fee of $\$ 501$ would need to be assessed.

Most trucks use some form of diesel fuel, and the cost to recover the additional damage caused by lifting the restrictions should be targeted at commercial vehicles. The current tax rate on fuel in Minnesota is $\$ 0.20$ per gallon for both unleaded and diesel fuel. Based on the consumption of diesel, and increase of $\$ 0.005$ per gallon on diesel fuel would recover the additional costs associated with the lifting of the SLR policy. A surcharge of $\$ 0.064$ would be necessary to upgrade the 7-ton roadways with a structural overlay. A weight-distance tax, such as that used in Oregon (Oregon Department of Transportation 2003) should also be considered.

\section{References}

Hashami, Maryam. “Operating Costs for Commercial Vehicle Operators in Minnesota.” M.S. Thesis, University of Minnesota, 2004.

Isakson, G. "State District Engineer Survey on Pavement Costs.” Technical Report, University of Minnesota, 2004.

Isotalo, Jukka. "Seasonal Truck-Load Restrictions and Road Maintenance in Countries with Cold Climate.” Infrastructure Notes: Transportation, Water and Urban Development Department RD-14, 1993.

Levinson, D., N. Li, X. Zou, B. Smalkoski, and M. Hashami. “A Framework for Analyzing the Effects of Spring Load Restrictions.” Transportation Research Record: Journal of the Transportation Research Board 1874, (2004):181-188.

Levinson, D., M. Marasteanu, V. Voller, I. Margineau, B. Smalkoski, M. Hashami, N. Li, M. Corbett, N. Funk, X. Zou, C. Peterson, D. Nagel, and S. Peterson. Cost Benefit Study: Spring Load Restrictions. St. Paul: Minnesota Department of Transportation and Minnesota Local Road Research Board, 2005.

Li, Ning, X. Zou, and D. Levinson. "Sharing Data Between Arc/Info and Emme/2: A Practice in Lyon County, Minnesota.” Proceedings of Transportation Research Forum's 2004 Annual Forum. Evanston, Illinois, 2004.

Oregon Department of Transportation. ODOT Transportation Development Division Policy Section and ECONorthwest. Volume I: Final Report 2003. Oregon Highway Cost Allocation Study Prepared for Oregon Department of Administrative Services, 2003.

Refsdal, G. “The Lifting of Axle Load Restrictions During Spring Thaw - A Norwegian Experiment.” Fifth International Conference on the Bearing Capacity of Roads and Airfields. Trondheim, Norway, 1998.

Refsdal, G., P. Senstad, and A. Soerlie. "The Lifting of All Seasonal Load Restrictions in Norway in 1995 - Background and Effects.” Transportation Research Board Annual Meeting, Washington DC, 2004.

Smalkoski, B. R. "Value of Time for Commercial Vehicles Operators.” Journal of the Transportation Research Forum 44, (2005):89-102. 


\section{Acknowledgments}

The authors would like to acknowledge the Minnesota Department of Transportation and the Minnesota Local Road Research Board for their financial support of the Cost/Benefit Study of Spring Load Restrictions.

Brian Smalkoski is currently working for Kimley-Horn and Associates, Inc. in Tallahassee, Florida, performing consulting engineering services. He received a B.A. degree with majors in geology and management, as well as a minor in economics from the University of Minnesota at Morris. He completed his M.S. degree in civil engineering at the University of Minnesota, Twin Cities, in 2003 .

Ning Li is a transportation engineer at the Virginia Department of Transportation (VDOT). He received a Bachelor of Science in civil engineering and a Bachelor of Economics in business administration from the Tsinghua University, Beijing, China, in 2000. He also has a Master of Management Science in engineering project management from the Tsinghua University (2002) and a M.S. in civil engineering from the University of Minnesota, Twin Cities (2005). Prior to VDOT, he worked for the Minnesota Department of Transportation and had several engineering internships in China, including working as site engineer on the Three Gorges Project in China.

Dr. David Levinson is an associate professor in the Department of Civil Engineering at the University of Minnesota. He is the author of four books: Financing Transportation Networks, Assessing the Benefits and Costs of ITS (with David Gillen), The Transportation Experience (with William Garrison), and Access to Destinations (with Kevin Krizek). 